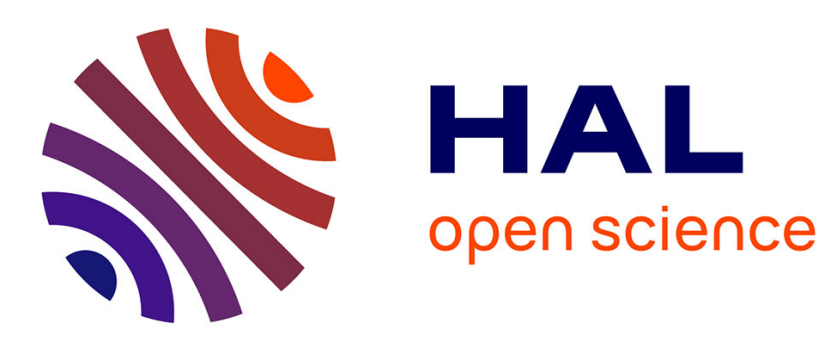

\title{
Upright Piracy: Understanding the Lack of Copyright for Journalism in Eighteenth-Century Britain \\ Will Slauter
}

\section{To cite this version:}

Will Slauter. Upright Piracy: Understanding the Lack of Copyright for Journalism in EighteenthCentury Britain. Book History, 2013, 16, pp.34-61. 10.1353/bh.2013.0011 . hal-01379239

\section{HAL Id: hal-01379239 \\ https://hal.science/hal-01379239}

Submitted on 31 Jan 2017

HAL is a multi-disciplinary open access archive for the deposit and dissemination of scientific research documents, whether they are published or not. The documents may come from teaching and research institutions in France or abroad, or from public or private research centers.
L'archive ouverte pluridisciplinaire HAL, est destinée au dépôt et à la diffusion de documents scientifiques de niveau recherche, publiés ou non, émanant des établissements d'enseignement et de recherche français ou étrangers, des laboratoires publics ou privés. 


\section{PROJECT MUSE}

\section{Upright Piracy: Understanding the Lack of Copyright for Journalism in Eighteenth-Century Britain}

Will Slauter

Book History, Volume 16, 2013, pp. 34-61 (Article)

BoOK History

Published by The Johns Hopkins University Press

DOI: 10.1353/bh.2013.0011

$\Rightarrow$ For additional information about this article

http://muse.jhu.edu/journals/bh/summary/v016/16.slauter.html 


\title{
UPRIght PIRACY
}

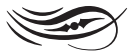 \\ Understanding the Lack of Copyright for Journalism in \\ Eighteenth-Century Britain
}

\author{
Will Slauter
}

When and how did written reports of current events-in other words, journalism-become recognized as a form of literary property? In Great Britain, the 1710 Act of Anne provided authors and booksellers with an exclusive right, during a limited period of time, to print, distribute, and sell their books. ${ }^{1}$ Yet the act made no mention of newspapers or other periodicals, whose status as literary property remained ambiguous well into the nineteenth century. The Literary Copyright Act of I 842 extended protection to "any Encyclopedia, Review, Magazine, Periodical Work, or Work published in a series of Books or Parts," but disagreement about the legal status of newspapers, not to mention the individual articles they contained, persisted. In the I830s and I85os, when the stamp tax on newspapers was lowered and then abolished, the managers of established London dailies feared a flood of cheap papers that would copy news acquired by them at great expense. They lobbied in vain for a special copyright that would prohibit the unauthorized reprinting of news reports for a certain number of hours after initial publication. ${ }^{2}$ The Copyright Act of I9I I offered explicit protection for newspapers, but by that time copyright was generally understood to cover only the precise language of articles, not the underlying factual details that many publishers now sought to protect. ${ }^{3}$

Because the Act of Anne did not mention serial publications, and because most court cases and discussions of literary property in the eighteenth century concerned the reprinting of books, it may be tempting to assume that periodical writings simply were not covered by the statute and that writers, publishers, and readers at the time did not view them as literary property in the same way as books. ${ }^{4}$ Evidence from the register of the Company of Stationers (the official record of copyright during the eighteenth century) and from the periodicals themselves suggests a more complicated story. Rather than simply assuming that contemporaries applied different standards depending upon the material form of publications (bound books versus single 
sheets) or the content of those publications (learned treatises versus accounts of recent events), it is necessary to study what they attempted to claim as literary property and how they attempted to do so.

In his book Piracy: The Intellectual Property Wars from Gutenberg to Gates, Adrian Johns argues convincingly for a broader history of piracy that considers the evolution of moral codes and cultural practices as well as developments in legislation and case law. Johns shows that complaints about piracy predated modern copyright laws, but also that the kinds of activity denounced as piracy have changed over time. ${ }^{5}$ In the case of eighteenthcentury journalism, evidence for contemporary interest in the problem of piracy appears not so much in the formal discussions of literary property usually studied by copyright scholars (petitions to Parliament, court cases, and pamphlets) as in the occasional comments of writers, printers, booksellers, and readers. Such comments tend to be more frequent and more elaborate during periods of increased competition, whether caused by changes in legislation or innovations in publishing practice. This article highlights two such periods: the I7IOS, a period of intense competition among the publishers of weekly essay sheets, and the I730s, when the appearance of monthly magazines led to the first sustained discussion of whether periodical writings could constitute a form of literary property. The debate in the I73os did not lead to any new legislation, but it did inspire changes in publishing strategy. Moreover, the fact that support for a copyright in journalistic texts was so limited for the rest of the eighteenth century demands explanation. At a time when literary property was the subject of numerous court battles and sustained debate in the press, why did so few people openly discuss a potential copyright in newspaper and magazine writings? What about these writings disqualified them from literary property in eighteenth-century Britain?

In order to better understand the ambiguous status of periodical writings under the Act of Anne, it is important to consider the extent to which this act differed from previous regulations and the established customs of the Company of Stationers. The act mentioned "books and other writings" in the preamble, but subsequent clauses referred only to "books" and "copies," and the stated justification of the legislation was to encourage "learned men to compose and write useful books." ${ }^{6}$ Before the Act of Anne, there had been two basic kinds of printing privileges. On the one hand, there were privileges granted by the monarch, which could cover a whole class of works (such as the Bible, Latin texts, or common law books) or protect rights in a single title. On the other hand, there were privileges resulting 
from entry in the register of the Company of Stationers. ${ }^{7}$ Neither type of privilege was limited to books. According to Hyder Rollins, ballads printed on one side of the sheet made up "the bulk" of entries in the Stationers' register during the late sixteenth and early seventeenth centuries. ${ }^{8}$ Although all printed works were supposed to be licensed and registered, many were not, and in the case of news publications the proportion of unregistered works may have been high. In the seventeenth century, as Carolyn Nelson and Matthew Seccombe have explained, "news of State was the property of the State. The public had no recognized right to political information." 9 But during periods when licensors authorized news periodicals, proprietors registered each issue and paid the same fee as for books. Such was the case for some of the weekly corantos that covered the Thirty Years' War in the I620s and for many of the Civil War newsbooks published in the I640s. ${ }^{\text {I0 }}$

In I 643 Parliament ordered "that no Book, Pamphlet nor Paper, nor part of such Book, Pamphlet or Paper" be printed without being first licensed and registered with the Company of Stationers. ${ }^{\text {II }}$ Intense competition among writers and printers of newsbooks led to accusations of counterfeiting and usurpation and to disputes over the right to use a particular title. ${ }^{22}$ After the Restoration, the Printing Act of 1662 imposed strict limitations on the production and sale of printed works and severely limited who could publish news. The act nonetheless specified a range of different forms of publication, including books, pamphlets, papers, ballads, charts, and portraitures, as being subject to the law and therefore eligible for the type of literary property it recognized. ${ }^{\mathrm{I3}}$

In 1695 the Printing Act lapsed, putting an end to prepublication censorship and the Company of Stationers' official monopoly over printing and bookselling. Over the next fifteen years the Stationers repeatedly petitioned Parliament for new regulations that would restore order to the trade. ${ }^{14}$ Meanwhile, the proliferation of newspapers raised the question of whether they should be licensed, but also whether in the absence of licensing such publications could be protected against piracy. Some of the bills considered by Parliament during this period would have recognized literary property in "any Book, Pamphlet, Portraiture, or Paper." ${ }^{15}$ And at least one of the tracts published during the months leading up to the Act of Anne complained specifically about piracy of newspapers. John How, a minor bookseller with a low reputation, argued that humbler and more topical works deserved protection alongside the learned and expensive editions usually emphasized in the Stationers' petitions to Parliament. ${ }^{16}$ "There is no ciliz'd State, or City in the World," How wrote, "where such an extensive Liberty is allow'd to 
any People as in this, where News, and all other sorts of Papers, are suffer'd to be pirated, and cry'd about the Streets by a parcel of Vagabond Hawkers, to the great Prejudice and Ruin of the just Proprietors of such Papers." ${ }^{17}$

The fact that the Act of Anne did not mention other forms of publication besides "books" therefore represented a departure from previous regulations and from recent discussions of piracy. The stated aim of encouraging "learned men to compose and write useful books" could be read as a sign that legislators intended not only to reduce the duration of property rights in books but also to limit the types of works eligible for such property. Yet the absence of specific references to periodicals, engravings, or musical scores did not automatically preclude these works from protection. Rather, the silence of the law meant that creators and distributors of such works had to petition Parliament for new legislation (as artists and engravers did), ask the courts to decide (as composers and music publishers did), or work out rules among themselves (as the owners of newspapers and magazines would do). ${ }^{18}$

As Ronan Deazley has explained, the Act of Anne was also ambiguous about the scope of the rights being granted to authors and their assignees. Did the act prohibit only the unauthorized reproduction and sale of an entire work, or did it also proscribe what would now be called derivative works, such as translations and abridgements? Eighteenth-century courts ultimately denied proprietors the exclusive right to control translations and abridgements, finding that such adaptations were consistent with the stated aim of the legislation, whose full name was "An Act for the Encouragement of Learning." Courts deemed that a translation could be an original work worthy of protection in itself; an abridgement could be permitted as long as it was "real and fair" rather than "a mere evasion of the statute." 19 Deazley admits that it is impossible to prove the intentions of the legislature, but he compiles enough evidence to demonstrate that the judges who upheld the right to abridge protected works were not out of step with trade customs at the time. As Simon Stern has argued, these judgments in favor of partial copying were also consistent with a literary culture that valued imitation, parody, and revision. ${ }^{20}$ Their work casts doubt on William St. Clair's claim that there was a "clampdown" on abridgments and anthologies during the seventeenth and eighteenth centuries that was not lifted until after the decision in Donaldson v. Beckett ( $\mathrm{I} 774$ ). ${ }^{2 \mathrm{I}}$ Similarly, a closer look at practices of reprinting in eighteenth-century periodicals suggests a much more fluid textual environment than St. Clair described for books. ${ }^{22}$ 
As with the right to control abridgments and translations, the Act of Anne was silent with respect to coverage for periodical writings. In the first ten years after the act went into force, a number of writers, printers, and booksellers experimented with the new law by registering their periodicals for protection. These included essay sheets such as the Tatler and the Spectator, newspapers like the Flying-Post and the Post-Man, and even a twiceweekly list of market prices. While some owners entered their periodicals in batches (tens or hundreds of issues at a time), others only bothered to enter single issues, presumably in response to or in anticipation of counterfeit editions. ${ }^{23}$ The validity of these copyrights was never tested in the courts during the eighteenth century, but the very fact that they were entered shows that concerns about the unauthorized republication of journalistic texts existed long before the invention of the telegraph or the rise of press agencies in the mid-nineteenth century.

A sustained period of complaints about unfair dealing in news followed the Stamp Act of I7I2. Newspapers printed on a half sheet of paper owed a duty of a halfpenny per copy; those printed on a whole sheet owed a full penny per copy. But the act failed to clearly define newspapers, and it contained no provision for periodicals printed on more than a full sheet of paper. Some printers increased the length of their publications and registered them as pamphlets instead of newspapers, thereby paying the much lower duty of $2 s$. per issue (regardless of the number of copies). Others evaded the tax entirely. Those who paid the duty had to raise their prices, and they began to express resentment for the unstamped papers that undersold them. ${ }^{24}$ Although they sometimes used the word "piracy" in this context, they did not complain about the unauthorized copying of individual texts so much as the cut-price tactics of the "pirate printers" who stole their customers, if not their news.

Many newspapers and periodical essay sheets were launched in the I7IOS, and most of them imitated existing publications. Such imitation often extended to the title of the periodical, sometimes leading to accusations of "passing off" one publication for another. ${ }^{25}$ The reprinting of whole issues of a periodical was another problem, and the existence of such counterfeit editions may explain why some printers and booksellers chose to enter periodicals under the Act of Anne despite the cost of registration. ${ }^{26}$ At the end of I 709 the most notorious pirate of the age, Henry Hills Jr., issued the first roo issues of the Tatler in a bound volume. Hills's piracy prompted Richard Steele and his associates to register the Tatler under the Act of Anne and to announce their own reprint sets in octavo and duodecimo. Hills's 
piracy thereby initiated an important eighteenth-century practice: reissuing periodicals in book form. ${ }^{27}$

Some writers and printers claimed exclusive use of a title on the grounds that they had pioneered a new type of publication embodied in that title. A prime example is the Weekly Journal, a publication launched by Robert Mawson in I7I 3 and imitated by John Applebee in I7I 4 and then by James Read in I7I 5. Mawson complained of "Two Pirating Printers [who] have published each a Sham Weekly Journal, at the Price of a Penny, . . . a bare Collection from the other Papers." ${ }_{28}^{8}$ Applebee attempted to protect his interests by registering his work under the Act of Anne, and he appealed to the public by renaming his paper Original Weekly Journal. Mawson registered his own work retrospectively, claiming ownership of "The Weekly Journal, from January Ist I7I4 to August the 27 inclusive I7 I 5." ${ }_{29}$ Yet this did not discourage others from printing similar publications with the same title, and eventually Mawson gave up his Weekly Journal to start a new publication called the News Letter. He stated, rather bitterly, that if his rivals recognized him as "the First Proprietor" of the Weekly Journal, then he would "give them free Consent under his Hand to Print Weekly-Journals, rather than They shall hang Themselves for want of other Employ." 30

Those concerned about the reprinting of individual texts from periodicals faced greater obstacles. The only way to avoid being copied was to change one's day or time of publication. In I7 I9, after appearing for several months on Thursday, the London Journal shifted to Saturday, making it harder for competitors (most of which also appeared on Saturday) to copy from it. Yet there was no way to stop weekly papers from recycling material from the dailies or evening papers from pilfering morning ones. The Evening Post (launched in I709) timed its publication so as to be ready to leave London with the evening mail for the countryside. Far from disguising its reliance on the morning papers, the Evening Post claimed to be providing a valuable service to its customers. A banner at the top of the page proclaimed, "This Paper comes out every Post Night at Six a Clock" and "contains the Substance of all the other News, with fresh Advices." ${ }^{3}$ Printing late in the day enabled the Evening Post (and its many imitators throughout the century) to reprint material from the morning papers while adding postscripts with late-breaking news. ${ }^{32}$

Printers in towns outside London also made a business out of reprinting. In promising local readers a convenient and low-cost digest of news from London, they were exploiting the idea that subscribing to a single London paper did not provide an adequate view of events; one needed to read sev- 
eral to be well informed, and the cost of postage made this very expensive. A newspaper appeared in Norwich as early as I70I, and by the early I720s there were over twenty papers in the provinces. Most of them relied heavily on the London press, and local printers made little claim to being original. Some of them even made conscious efforts to disown the material they reprinted by naming its source, making it clear that they were not responsible for the accuracy of reports. ${ }^{33}$

Within London, booksellers became important investors in newspapers, which promised them a steady income and a guaranteed channel for advertising their books. Booksellers bought and sold shares in newspapers, and by 1730 group ownership was the norm. ${ }^{34}$ Despite their financial stake in newspapers, booksellers did not call for a special copyright in periodical writings or set up trade customs to control the publication of news. Several periodicals had been entered under the Act of Anne during the I7Ios, but after this initial period of experimentation such entries became relatively rare. The booksellers and other shareholders of newspapers handed daily operations over to printers and editors who culled other papers looking for paragraphs and essays to reprint, especially material that they could use to mock or criticize their competitors. Such one-upmanship was a major feature of the London press, and as long as newspapers were doing well financially and providing them with an outlet for advertising, the bookseller-owners would have had little reason not to tolerate the copying of individual articles.

The appearance of the first successful monthly magazines in the early I730s created additional competition, and this led booksellers to consider more seriously the question of who owned the individual paragraphs and essays that made up each issue of a periodical. The Gentleman's Magazine, launched by Edward Cave in I73 I, openly advertised the fact that it contained a digest of news and essays from the newspapers. In the early I730s, Cave emphasized utility rather than originality, and this utility depended upon copying. ${ }^{35}$ Like the printers of provincial newspapers, Cave claimed to be serving readers by selecting, editing, and reprinting a range of sources at a fraction of the original cost. The Gentleman's Magazine proudly claimed that it was "very proper for private Families, or to send into the Country, and Places abroad, where the English reside; being a compendious View of all our publick Papers." ${ }_{36}^{6}$ An engraving that appeared on the title page of each issue beginning in September I73 I illustrated how Cave built upon existing publications to create a new structure. The image was of St. John's Gate, the office of the Gentleman's Magazine. Buttressing the gate on both 
sides were the titles of publications the magazine drew upon for its content: the London Gazette, London Journal, Fog's Journal, Applebee's Weekly Journal, and dozens of other titles appeared stacked upon each other like so many bricks holding up the edifice of the Gentleman's Magazine (Figure I). Far from hiding his reliance on other publications, Cave used their titles to attract customers.

The booksellers who combined to form the London Magazine in $\mathbf{I 7 3 2}$ were inspired by the success of the Gentleman's Magazine, but they also had specific reasons to resent Cave's publication. At least three of them-John Wilford, John Clarke, and Thomas Astley-owned shares in the Monthly Chronicle (I728-I732), whose mix of news and listing of recent books now seemed threatened by the Gentleman's Magazine. Some of them also had stakes in the weekly papers whose articles Cave was reprinting. Wilford was the main shareholder of Fog's Weekly Journal. Clarke had a stake in the Weekly Register, as did the printer Charles Ackers, who also became a shareholder in the London Magazine. ${ }^{37}$ With Cave acting on his own and with no easy remedy at law, these men may have seen little choice but to join him in the business of reprinting material from daily and weekly publications in a new monthly form.

The London Magazine ridiculed its predecessor while imitating it in almost every respect. Like the Gentleman's Magazine, the London Magazine was divided into two parts. The first, entitled "A View of the Weekly ESSAYS and DISPUTES in this Month," consisted of excerpts, and sometimes complete essays, taken from a variety of publications. The sources of these essays were generally acknowledged, as was the date of original publication. The second part of each issue consisted of "the Gentleman's Monthly Intelligencer," and the similarity of this subtitle with that of its rival (Gentleman's Magazine; or, Monthly Intelligencer) offered a good example of how eighteenth-century publishers piggybacked on the success of their competitors. The game involved a mixture of mockery and imitation. Referring to the two magazines as "brothers," the Grub-Street Journal described how the London Magazine ridiculed the Gentleman's Magazine, while "at the same time he endeavoured to establish his own credit and reputation, especially among people in the country, by passing for him. To this end he gave out printed bills of his own name, titles, motto, \&c little different from those of his brother." ${ }^{8} 8$

The Grub-Street Journal, a satirical weekly published from I730 until I737, lost no opportunity to criticize unscrupulous printers and booksellers. Richard Russel, its editor and main writer, had a particular interest in 


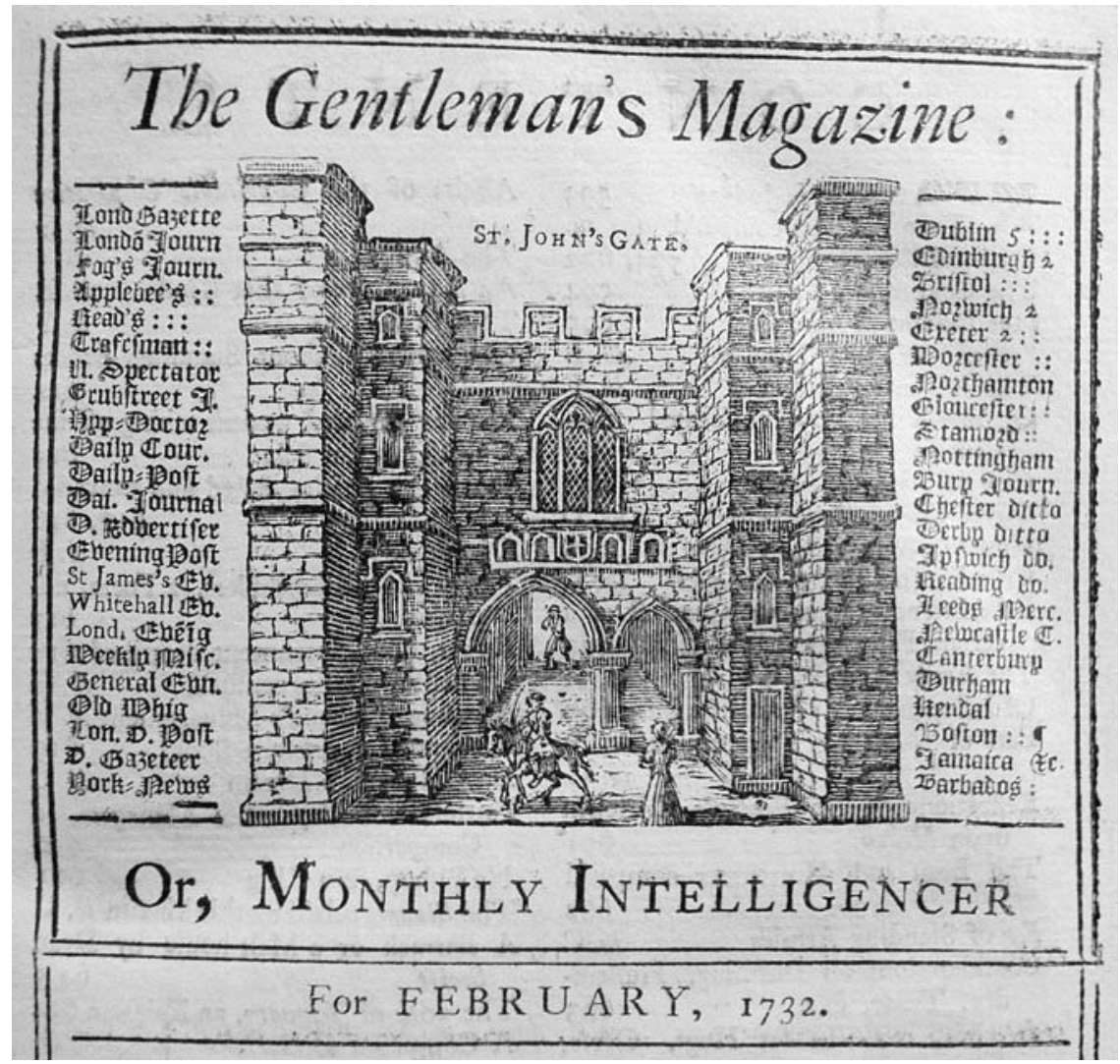

Figure I Close-up of the engraving featured on title pages of the Gentleman's Magazine (this version from February I732). Reproduced with permission of the University of Chicago Library.

piracy, and much of the feud between the Gentleman's Magazine and the London Magazine played out in his paper. ${ }^{39}$ Even before Russel addressed the subject directly, he allowed readers to watch the rivalry unfold in the increasingly aggressive advertisements that the two magazines inserted (often side by side) in the Grub-Street Journal. On May 4, I732, shortly after the London Magazine first appeared, Cave used one of these ads to complain of the new publication as an unfair imitation:

The Customers to the GENTLEMAN'S Magazine, or Monthly Intelligencer, are desired to take Care that they are not deceived by a 
Book with a similar title, which will be offer'd them at some Shops, and as they have been so kind to encourage this useful Undertaking, it is hoped they will not, by any Arts, be misled to favour an Attempt so unfair and ungenerous as the supplanting an Author in his whole Plan, Design, and even Title. A Practice which would be condemned by every Individual concerned in it, if their own Case. And the Public may be assur'd that whatever our Rivals may pretend, nothing shall exceed this Magazine. ${ }^{40}$

Cave's proud notices soon drew the ire of the men who owned the London Magazine. An advertisement in the Grub-Street Journal, framed as an open letter to Cave, complained that he was drawing upon publications that he did not own. "Your Assurance, we think, is very extraordinary, in reflecting upon us for compiling a Book of this Kind from the Public Papers, in several of which we have a Property, when you have not the least Share in any one of them; which makes your Work little better than a downright Piracy." ${ }_{41}$ The proprietors of the London Magazine argued that they had a right to reprint excerpts from the weekly papers because they had an ownership stake in them. Their claim obscured the complexity of group ownership. The London partners did not have shares, let alone complete ownership, of all of the publications from which they copied, nor did they claim to have asked permission to reprint content from papers they did not own. In discussing this point, Iona Italia has argued that "the London's editors had no legal basis for their 'property' in 'the public papers,' as there was no copyright on periodical material." " ${ }^{2}$ Such a conclusion assumes that contemporaries agreed on what was covered by copyright (hardly a safe assumption), and obscures what the London Magazine's partners were trying to do. Their initial strategy was to highlight Cave's status as a printer for hire, as opposed to an author or bookseller with property rights in the texts being printed. They were emphasizing rights based on trade customs rather than the Act of Anne, but they were also testing the limits of such customs with respect to periodical writings.

Responding to the charge that he was a printer and therefore had no right to other people's texts, Cave pointed out that one of the partners in the London Magazine, Charles Ackers, was also a printer. Sticking to their original argument, the London Magazine's partners insisted that "Mr Ackers (tho' a Printer, as well as Mr Cave) is qualified for being a Proprietor, by being a Partner of the Weekly Register; which Mr Cave is not; therefore every Essay, or Poem, which is taken from thence, is his Right, and Mr Cave is the Supplanter." ${ }^{43}$ Cave rejected the idea that "half a dozen Men have a 
Right to publish Abridgements." He had just as much "Right to the publick Papers" as anyone else. ${ }^{44}$

As Italia has pointed out, Cave also presented a positive argument, defending his right to reprint texts on the grounds that his careful selection and arrangement of them provided a service to the public. ${ }^{45}$ In doing so he suggested that the property resided not in the individual texts that made up a given issue but in the periodical's overall design. What was unfair, according to Cave, was the close imitation of his "plan," "method," and "title." "In setting out the Gentleman's Magazine, we publish'd our Design a Month before; and took care not in the least to clash or interfere with the Title, Method, Form or Plan of any Book in being, that it might have no Dependence but its own Worth." ${ }^{46}$ In fact, Cave's was not the first monthly compilation, nor was it even the first to use "Gentleman's" in the title. But Cave's was the first periodical to use the term "magazine," a word previously associated with military storehouses. ${ }^{47}$

The London Magazine's partners responded to Cave's design claim by insisting that nobody had an exclusive right to print or sell a particular type of publication. "As to supplanting you in your Design, pray, Sir, who gave you (a Proprietor in no one Paper) a Right, exclusive of all others, even of Proprietors themselves, to a Design of this Nature? In other Cases, where Persons are upon a Level, (as you are not with us in this Case) one and the same Design lies open and free to several, to execute in the best Manner they can. Is not this the Case of Manufactures, of Arts and Sciences, and of News Papers themselves?" ${ }_{48}$

The London Magazine's partners thus divided the issue in two. With respect to reprinting, they claimed that an ownership stake in a periodical came with exclusive rights to republish texts that first appeared in that periodical. With respect to design, they claimed that no such rights existed. Everyone could offer their wares to the public and let the public decide their worth. The London Magazine's partners even proposed a contest in which the public would judge the two magazines "as to Compiling, Paper, and Letter.”

Russel, the editor of the Grub-Street Journal, showed particular interest in this controversy. Writing under the pseudonym "Bavius," he quoted the arguments of both sides and then tried to imagine how Cave might respond to the claim that an ownership stake in several newspapers gave the owners of the London Magazine exclusive reprinting rights. First, he questioned how the London Magazine's partners could be so sure that Cave did not have a stake in any of the papers he used. If he did have a share in one or sev- 
eral of the papers, then "the whole argument against him fell to the ground, being built upon one supposition, that a share in any one paper gives a man a right to reprint any other, in whole, or in part." Bavius then attacked the logic of the argument, insisting that "the right cannot possibly extend any farther than the share, which can only intitle a man to reprint a part of any one paper, proportionate to his own concern therein." He then mocked the booksellers for claiming that Cave had committed a "downright piracy." If that was the case, then the London Magazine's shareholders, by reprinting from papers that they owned, had committed an "upright piracy."

Yet Bavius ultimately sided with the London Magazine's partners in concluding that imitating others' designs was less harmful than reprinting their writings. Moreover, he suggested that current copyright law was inadequate because it did not protect against the kind of piracy being committed by the Gentleman's Magazine. "If one author endeavoured to supplant another, only by stealing his plan, design, and title, the latter may in some measure remedy that evil, by executing his design in a manner superior to that of the former. But when one person publishes the works of another, in such a manner as comes not within the letter of the law, it is a damage, for which it is not in the power of the injured to procure any reparation." 49

Bavius's essay drew the ire of Cave, who responded by accusing the GrubStreet Journal of being just as piratical as the Gentleman's Magazine. After all, both the magazine and the journal reprinted material from the daily and weekly papers. ${ }^{\circ}$ Bavius then felt compelled to set the record straight on the difference between his journal and Cave's magazine. "The news which we take from the daily papers makes about one half of our Journal, advertisements excepted; the rest consists of original compositions. The Gentleman's Magazine is nothing but a collection from other papers and pamphlets, without any original compositions at all." Yet Bavius was not content with simply pointing fingers at Cave. He was genuinely interested in the question of a potential literary property in news reports, which he promised to discuss at a later date, when he would demonstrate "that our method of comparing the articles of one paper with those of another, is not only not piratical, but extremely useful, and even necessary to put a stop to the currency of false news." ${ }_{5 \mathrm{I}}$

In I734, again writing as "Bavius," Russel elaborated his argument about the public utility of the kind of reprinting done by the Grub-Street Journal. Weekly journals had long contained "abbreviations" of the daily papers, he explained, but individual paragraphs often contradicted one another, and since the journals rarely indicated their sources, readers had no way to de- 


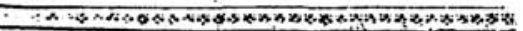

D O M E T I C NEW S.

C. Daily Courant.

P. Daily Poll-Boy.

D P. Dai,y Pof.

D J. Daily Gournal.

DA. Daily Advertijer.

S J. St. Fames's Evening PöR. W E. White-ball Evenitg $P o /$. L E. London Evcning Polt.

i Thursoay, Ang. 1. Yefterday their majelties, \&c. hunted a buck in Richmond Neiv Park, for the firft time, scc. $P . D A$. A ftug. $D P$. — A hind. $D \mathcal{J}$. Which afforded fome hours diverfion. $P$.

Very good diverfion near two hours. $D P$. $D A$. Excellent fport. DF. - It lafted little more than an hour : the dogs, hiving eaten in the night a whole dead horfe, were nor keen enough to afford niuch diverfion. LE. - "Ibefe contradialions are good diverfion to tbe reader.

This being the anniverfary of the happy accefiion of his late majelly to the throne, there will be a fiplendid couit at Kenfington. $D A$. Mr. Dogget's coat and bidese will be rowed for. C. DP. DY. - The hon. Artiliery company will perform a fine exercife at arms. DP. - Tbefe propbicies were all exalaly fulfilled, as we are affured by WE.

Dirt, on monday, Chriftoph. Ridout, of Blandford, Elig; poffefs'd of a very large eftate. $D P$.

Inzfortant articles. Yefterday a man was committed to the Naw Gaol in Southwark, for breaking open a houfe. C. At the Artillery grourd, a match of cricket was played, between the gentlemen of Croydon and thole of London; and won by the latter. $D A$.

On monday at Limsfield many perfons did fare,

To fee the 201. plate won by Mr. Clark's wall-ey'd mare. $C$.

On tuefday the ro 1 . purfe, zobicb was rais'd by a club.

Was won by a grooun's horfe, which was called Fox-cub. C. DP.

FRIDAY, Aag. 2. Yefterday the Indian king and queen were carried with their attendance in the king's coach to Kenfingtorl, \&e. C. The Indian kings or chiefs in 3 coaches. DP. Drawn-by 6 horfes each : their robes were of the Moorilh fifhion. $D F$.

About one, Sir Clement Cotterel, with 3 coaches and fix cume to the Truftees office for Georgia in Old Palaceyard, and proceeded with the Indian chicfs and the interpreter to Kenfington. His majefty received them feated on his throne in the prefence chamber, and Tomo Chachi, Micho, or king of Yamaeraw, made a fpeech, to which his majefty return'd a moft gracious anfwer. They next waited upon her majefty, who was feated on a throne in the great gallery, to whom Tomo Chachi addrefs'd himfelf in a fhort fpecch, to-which he anfwer'd very graciouny. Her majefty took particular notice of Tooanakow $\mathrm{i}$ his nephew (a youth about 13 ) and asked him feveral queftions, who anfwer'd in Englinh in fuch a manner, that her majefty was extreamly pleafed. $D A$.They will be kept at the king's expence, his majefty having ordered $20 \mathrm{~L}$ a week for that purpofe. $D \mathcal{F}$.

Mr. Dogget's coat and badge were won by one Matham, who plies at Black-lyon ftairs. P.DF.

lows. DP. - By one Sanbick. DA.

Yefterday Mr. Doddington was chofe a director of the bank of England, in the room of Boheme deceafed. C. Mr. John Eaten Dodsworth was eleoted. DF.

The right hon. the lords commiffioners of the Treafury have appointed $\mathrm{Mr}$. Ralph, to be furveyor of houfes in the county of Cambridge, in the room of $\mathrm{Mr}$. Shute deceafed. P. - Mr. Atticus is in bopes of jeeing $a$ Critical Review of thefe houfes.

Married, laft monday fe'nnight, her grace the dutchefs Dowager of Norfolk, to Peregrine Widdrington, Efq; $P$.

Important articles. On wednefday one Powel, a milkman in Bembridge-ftreet, St. Giles's, hang'd himfelt with a handkerchief, on a place fo low, that he was obliged to fit down to do it. $D \mathcal{D F}$.
Figure 2 Excerpt from the Grub Street Journal for 8 August 1734 (p. 2, col. I) showing the juxtaposition of reports from different sources. Reproduced with permission of the British Library. 
termine the authenticity of the news. The Grub-Street Journal, by contrast, printed reports on a particular subject one after the other, always indicating the name of the newspaper that had originally published them (Figure 2). Like certain news blogs on the Internet, the Grub-Street Journal excerpted and juxtaposed divergent accounts in an attempt to facilitate commentary and criticism. ${ }^{52}$ This format enabled readers to compare multiple versions of the same event or combine details from several into a composite account. The novelty of this approach was announced in an early advertisement for the Grub-Street Journal, which promised readers "a large and most authentick Account of all the News both DOMESTICK and FOREIGN; collected in a new Method from all the Papers of the preceding Week; with short Remarks Serious and Comical, showing the BEAUTIES, the DIFFERENCES, and the MISTAKES which occur in them." ${ }_{33}$

The Grub-Street Journal was not the first paper to promise to label its sources to help readers make sense of the news. In the first issue of the Daily Courant (I702), the printer announced that he would not "under Pretence of having Private Intelligence, impose any Additions of feign'd Circumstances to an Action, but give his Extracts fairly and Impartially; at the beginning of each Article he will quote the Foreign Paper from whence 'tis taken, that the Publick, seeing from what Country a piece of News comes with the Allowance of that Government, may be better able to Judge of the Credibility and Fairness of the Relation." ${ }_{54}$ Acknowledging the source and preserving the integrity of the report would help readers determine the authenticity of the news. Although the printer promised not to present copied news as his own, he did so in hopes of earning the trust of his own readers, rather than out of some perceived debt to the originator of the report, who almost always remained anonymous. Other newspapers echoed this promise to copy "faithfully" and label the source of the news, but few made good on it, and the practice of citing sources remained irregular throughout the eighteenth century and well into the nineteenth.

The Grub-Street Journal was innovative in printing reports on the same subject one after the other, labeling the source of each detail with initials such as DA for the Daily Advertiser and LE for the London Evening Post. Most of the time the close juxtaposition of contradictory details spoke for itself, but sometimes the editor added ironic remarks like "this article is added to shew the truth of the former." 55 The news section was humorous and informative, but it must have been a lot of work. The Grub-Street Journal was unique in sustaining this editorial practice over the course of several years, but a few other contemporary papers did imitate it briefly. In the late 
I730s, for example, the North Country Journal (based in Newcastle) indicated the sources of each news item, and the abbreviations it used resembled those found in the Grub-Street Journal. In the mid-I740s the Reading Journal showed a similar interest in labeling individual articles, but chose to mark only those that had appeared in a single paper, leaving unlabeled those texts that had appeared in several papers. ${ }^{56}$

Russel defended his conscientious form of reprinting against charges of both plagiarism and piracy. He defined plagiarism as "the surreptitious taking of passages out of any author's compositions without naming him" and piracy as "the invasion of another's property by reprinting his copies to his detriment." He continued, "a work cannot be justly charged with either of these, in which the author is constantly quoted, and such things reprinted wherein another can claim no peculiar property, or from the reprinting of which he can receive no damage or injury." Russel claimed that plagiarism did not apply because the "author" of each article was named, but in fact only the title of the publication was given. As for the charge of piracy, he insisted that no damage could be done to property that did not exist in the first place. "No man can assume to himself a Property by employing persons to collect a heap of trivial, ridiculous, and false paragraphs of news; and then publishing them dayly [sic] to the world." ${ }_{57}$ For Russel, the people involved (casual employees rather than authors), the work process (collecting rather than writing), and the final product (trivial, ridiculous, and false)—all worked against the idea of a literary property in news.

Russel applied a different standard to the poems and literary essays appearing in periodicals. "It has been a frequent practice among our Dissenting Grubean brethren, employed in Daily, Weekly, or Monthly Papers or Pamphlets, to take out of our Journal Poetical Pieces especially, and to reprint them as their own, without the least acknowledgment from whence they had them: this we take to be plagiary, piracy, or literary theft, in the properest sense. ${ }{ }^{8}$ Given the clarity of Russel's distinction between plagiarism and piracy in his discussion of news, this statement appears ambiguous. Was he upset that the poems had been reprinted or that the Grub-Street Journal had not received credit for them? The example that he provided suggested that it was the failure to acknowledge the source that constituted the "literary theft": Russel explained that the Post Boy reprinted verses that had first appeared, upon the author's request, in the Grub-Street Journal. "To conceal the theft, [the editor of the Post Boy] has put IRELAND at the head of them; as if he had received them from that kingdom. A trick which others, as well as himself, frequently make use of, with a different view, viz. 
to put off here, as the compositions of some Wit at Dublin, the real productions of some latent member of our Society." 59

Russel's example highlighted a major cultural obstacle that stood in the way of establishing shared protocols of citation during this period: in some circumstances editors and printers preferred not to name their source and thereby assumed credit for publishing the text; at other times they took pains to identify the source so as to avoid responsibility for the views being expressed; and in still other cases they found it advantageous to deliberately mislabel the origin of the material.

Not all eighteenth-century printers and editors agreed with Russel's distinction between news paragraphs, which he thought should be open to copying, and essays, which he thought should be treated as literary property. After all, not all paragraphs were alike. In I 737 the writer of a weekly paper called Common Sense claimed that his contributors

now and then make some little Remarks upon Events that happen in the World, which they chuse to throw out by Way of Paragraphs rather than introduce them into their Essay; and which they observe are constantly stolen by the London Evening Post, without any acknowledgement from whence he has them;--We hereby order the said London Evening Post to keep to his own province of stealing silly paragraphs of Domestick Newes wherever he can pick them up, not meddle upon any pretence whatever with Things which are onely designed for Common Sense.- If they goe on to commit these Depredations they shall hear of It in a Manner that wil doe them no Service. ${ }^{60}$

The writer distinguished not between paragraphs and essays but between two different types of paragraphs-those containing news that could be found in a number of papers and those that were written specifically for Common Sense-though he did not explain how readers or competitors could know the difference.

What about reprinting essays on literary or political subjects that appeared in other periodicals? The Grub-Street Journal made an interesting remark on this subject after a correspondent suggested that it republish essays from the Tatler, the Spectator, and the Guardian "either in weekly numbers, or in a sheet added to our Journal." Russel did not see the use of doing so since the essays were already available in book form "and may be purchased at a reasonable rate by all such as are capable of reading them." He also cited the problem of literary property. As greedy as some booksellers may 
be, Russel thought that "they have a right to those copies," and "it would be a breach of morality to reprint them as our own." ${ }^{61} \mathrm{He}$ seems to have lamented the lack of clarity in the law and hoped for an ethical solution to the problem of reprinting. As another example of unfair dealing not adequately covered by the statute, he mentioned the tendency of newspapers to reprint accounts of trials that had appeared in separate publications. Whether the subject was history, divinity, or crime, "we cannot reconcile this practice with the rules of common honesty; which a man may transgress in many instances, without exposing himself to the penalty of any human law." ${ }_{22}$

Attempts to reform copyright legislation in the I73os offered an opportunity to clarify the law with respect to periodical writings, but this opportunity was lost. In 1737 a contributor to the Grub-Street Journal who signed his letter "PHIL. FILCH" wondered why periodical writings were not included in the new bill being proposed by London booksellers. He wished that the bill "were drawn much fuller than I hear it is; that so the Grubstreet Journal might be secured to its Proprietors, free from the depredations of the Magaziners." ${ }_{63}$ That he singled out Cave as the chief culprit was not surprising given the previous quarrels between the Grub-Street Journal and the Gentleman's Magazine. Yet the idea advanced by PHIL. FILCH-that journals and magazines should be given statutory protection similar to that provided to books and engravings-raised a number of questions. Would each paragraph, letter, or article need to be registered? Would news reports be included as well as poems and essays? PHIL. FILCH did not specify, and nobody else seems to have stepped forward with a more concrete proposal. Instead, another contributor who signed his letter as PHIL. ARET dismissed PHIL. FILCH's suggestion, shifting the focus from copyright to the nonmonetary rewards available to authors. "I assure you, Gentlemen, that I have been a Contributor to your Journal, and when any Pieces I sent, were convey'd from thence into the Magazine, it gave me a sensible pleasure." ${ }_{64}$ In other words, it felt good to be copied.

Many individual contributors to periodicals may have agreed that seeing one's words in print was gratification enough. Some editors, like Russel, also desired acknowledgment for their work, not by being named personally but by having their publication mentioned whenever material was copied from it. But Russel also believed that poems and essays appearing in periodicals should be treated as literary property, and he was frustrated that there was no way to stop men like Cave. ${ }^{65}$ By reproducing poems and epigrams "verbatim and at full length" without mentioning their source, Cave was trying to raise the reputation of his magazine and promote its sale, "as sto- 
len linen, handkerchiefs, \&c. are rendered the fitter for sale, by taking out the mark of the owner's name." ${ }^{66}$

Russel blamed Cave for the ruin of the Grub-Street Journal (which ended in 1737) and other weekly papers. Leaving aside material gleaned from pamphlets and books, Russel estimated that each issue of the Gentleman's Magazine pilfered material from over forty issues of various weekly papers, whose combined owners had paid a total of 20 guineas in "Copy-money." ${ }_{67}$ The source of Russel's estimate remains obscure, but a sum of 20 guineas for forty issues would yield an average payment of half a guinea for the leading essay of each one. A decade later the Westminster Journal promised the same rate for contributions "that fill up the whole Space usually allotted to Pieces of that Nature." ${ }^{68}$ But the scant evidence we have about payment for contributions suggests a highly varied practice. Some newspapers had writers on salary, but most paid for occasional submissions while depending on material copied from other newspapers or sent by unpaid correspondents. ${ }^{69}$

Although Russel's estimate of 20 guineas spent on "Copy-money" cannot be accepted at face value, it also cannot be dismissed. His goal was to show that Cave's piracy had economic consequences for the periodicals concerned. He took it for granted that the monthly magazines had cut into the sales of the weeklies, causing their combined circulation to fall by thousands of copies a week. ${ }^{7}$ In terms of total cost, payments for occasional submissions paled in comparison to the sums advanced to cover the stamp duty, and Russel lamented that exemption from this tax provided the monthly magazines with yet another unfair advantage over the weeklies. Looking back on the early years of the Gentleman's Magazine, he expressed surprise that such a "mean undertaking" had been encouraged by readers, and that neither the stamp commissioners nor the shareholding booksellers made any serious efforts to stop it. Instead, the partners of the London Magazine imitated Cave by creating a "piratical pamphlet" of their own. Russel lamented that booksellers did not adhere to a moral code that would have prevented them from pillaging each other's works. "Had such notions of right and wrong generally prevailed, the Gentleman's Magazine had either never appeared at all, or had at least been soon forced to disappear." ${ }^{11}$

Russel's experience led him to the conclusion that booksellers would continue to take advantage of imperfect laws to make easy money. "If the reprinting of another person's Copy be not expressly forbidden, they imagine themselves at liberty to do it for their own private interest." Although periodical writings were not mentioned in the Act of Anne, Russel insisted that they were a form of literary property governed by natural law. "A 
person who composes any thing in writing intended for the benefit of others, has a right to some advantage by way of grateful return from them, for that product of the labour of his mind, as well as for the product of any bodily labour. This original right he may transfer by gift, or for some valuable consideration, to any person, who from thenceforth becomes the sole proprietor of that production." ${ }^{72}$ Since the booksellers were not intent upon following natural law, Russel thought that the statutes should be revised to provide more protection against piracy. "Unless the Bill now depending put an effectual stop to it, the chief business of Book-selling will consist in the execution of piratical projects, to the great disadvantage of the fair trader, as well as of the Public." ${ }^{73}$ Russel may have been referring to the bill proposed by London booksellers in 1737 , but this proposal did not specifically mention periodical writings. ${ }^{74}$

Although Russel remained a lone voice in calling for property rights in periodical writings, other authors and booksellers did express concern about the reprinting of books (or excerpts of books) in periodicals. No eighteenthcentury court seems to have addressed the question of whether a text first published in a periodical could be protected against unauthorized republication in another periodical. ${ }^{75}$ On the other hand, proprietors did petition for injunctions to stop periodicals from publishing excerpts and abridgments of their books. As Deazley has shown, Cave was at the center of these lawsuits. In 1739 he was sued for reprinting extracts of Joseph Trapp's The Nature, Folly, Sin and Danger of Being Righteous Over Much in the Gentleman's Magazine. The court granted a preliminary injunction, but Cave insisted that for several years he had been reprinting "short extracts, parts of books, pamphlets or other writings newly published" without complaint. He argued that the legislature could not have intended to prohibit limited extracts, because such a restriction would be "greatly prejudicial to the spread of knowledge and learning." ${ }^{6}$ The Lord Chancellor found Cave's arguments inadequate and offered him more time to resubmit them. Cave apparently did not do this, which left the injunction standing. ${ }^{77}$

Cave obtained a more favorable verdict a few years later. In 1743 he planned to reprint parts of Elizabeth Haywood's The Unfortunate Young Nobleman, and the proprietor of that title requested an injunction. In his response (which has not survived), Cave asked for the injunction to be dissolved unless the plaintiff provided sufficient cause. The plaintiff failed to do this, which meant that Cave could reprint. A later case, Dodsley v. Kinnersley (I76I), provided a more substantial ruling in favor of the right to reprint excerpts from books. The case involved the reprinting of an excerpt 
from Samuel Johnson's Rasselas in the Grand Magazine of Magazines. Estimating that the extract represented less than one-tenth of the first volume of the original work, the judge thought "it may serve the end of an advertisement." More important, the plaintiffs had already planned to publish an abridged version in the London Chronicle, and the judge did not see how a second abridgement in the magazine could be harmful. He refused the injunction, confirming the legitimacy of the kind of reprinting that Cave and others had been defending since the 1730 s. $^{78}$

The arrival of the magazines was not the only reason that the I 73 os marked a turning point in London journalism. As Michael Harris has explained, the late I 720 s and early I 73 Os had been a favorable moment for the creation of literary and political weeklies. Many of them, like the Grub-Street Journal, did not last into the I740s. ${ }^{79}$ With important exceptions like The Craftsman (I726-I752), most weeklies could not compete with the dailies and triweeklies for freshness of news; nor could they match the range of material published in the magazines. Robert Walpole's fall from power in $\mathrm{I}_{742}$ deprived the weekly essay writers of their favorite subject. ${ }^{80}$

Moreover, in the middle decades of the century, a particular kind of newspaper, the commercial advertiser, came to dominate the trade. It became a forum for all kinds of texts, including original essays and excerpts from pamphlets. Essay sheets enjoyed another moment of success around midcentury with Samuel Johnson's Rambler (I750-I752), John Hawkesworth's Adventurer (I752-I754), and Henry Fielding's Covent-Garden Journal (I752), but by the I76os the "evening posts" and "advertisers" clearly represented the dominant mode of English journalism. Papers like the London Evening Post (I727-I806), Public Advertiser (I752-I794), Gazetteer and New Daily Advertiser (I764-I796), and Morning Chronicle (I769-I865) offered a successful mix of foreign news, essays, poems, letters, price lists, and advertisements. Extensive coverage of parliamentary debates beginning in the early I 770 s marked a shift away from foreign news toward national and imperial politics, and this further reinforced the newspaper's importance as a venue for public opinion..$^{8 \mathrm{I}}$ In the days of Addison and Steele, newspapers had focused on bulletins of military and diplomatic news, leaving room for the weekly essay sheets to explore social and political issues in more detail. By the I770s such essays were integrated into the pages of newspapers alongside news paragraphs, literary reviews, excerpts from pamphlets, and accounts of parliamentary debates. 
For these newspapers, reprinting was both practical and politically defensible. In a world before press agencies or professional reporters, almost all of the nonlocal news came from publications printed in other cities and countries. The basic nugget of news was the paragraph, a textual unit that could be easily detached from one source and inserted into another. The type had to be set locally, which gave printer-editors the opportunity to modify texts for their local audience. In the process they often stripped paragraphs of references to the circuitous path that they had taken. Removing references to intermediate sources and adhering to the geographic presentation of news enabled editors to impose order on a diverse range of textual material, most of which came not from correspondents but from other publications, including the manuscript newsletters that continued to circulate during the eighteenth century. ${ }^{82}$

Newspapers based in London also copied from each other, not only to save on the translation of foreign news but also to engage in debate on local and national issues. Over time the paragraph became a journalistic genre in itself. The writer for Common Sense already suggested as much in I 737 when he complained about other papers unfairly copying paragraphs submitted by contributors. But for most writers and politicians it was the fact that such paragraphs were open to copying that made them useful as tools of persuasion. ${ }^{83}$ By the 1760 s writers across the political spectrum were exploiting the paragraph as a weapon in the battle for public opinion. John Campbell, a writer employed by Lord Bute to counter the arguments of John Wilkes and his supporters, described the process: "I have . . very carefully watched all the Inflammatory Paragraphs that have appeared in the Papers and have encountered them by other Paragraphs better founded as well as of a better tendency." ${ }^{4}$ Two decades later, Charles James Fox described how the paragraph fit into an overall publicity strategy: "Subjects of Importance should be first treated gravely in letters or pamphlets or best of all perhaps a series of letters, and afterwards the Paragraphs do very well as an accompaniment. It is not till a subject has been so much discussed as to become almost threadbare that Paragraphs [that] consist principally in allusions can be generally understood." ${ }_{55}$

For printers and editors, copying was what enabled the news to spread. For a newspaper's shareholders, what mattered was the financial health of the publication and its ability to attract advertisers. Investments in newsgathering remained minimal during the eighteenth century and therefore so did claims of proprietary information. From time to time editors and printers complained about copying, and some of them tried to assert exclusive 
rights over particular kinds of texts. In the I750s the Lloyd's association of insurance brokers, which published a twice-weekly account of shipping news called Lloyd's List, threatened to prosecute provincial newspapers that reprinted its reports. A Manchester paper that received such a notice informed its readers that it would stop publishing shipping news "until we are thoroughly inform'd of the Legality or Illegality thereof." ${ }^{86}$ Many country printers simply gave into the demands of London publishers. The official printer to the House of Commons claimed exclusive rights to election returns, and this led a Bristol printer to apologize to his readers for not publishing them. Likewise some local newspapers were reluctant to reprint the king's addresses to the Houses of Parliament or the full text of laws, because the printing rights for such material belonged to patent holders. ${ }^{87}$

Yet such ownership claims were rare with respect to most of the texts that filled eighteenth-century newspapers and magazines. No printer or editor would have dreamed of prohibiting the copying of paragraphs, because that would have made it much harder to fill his own columns. Politically speaking, it had also become more difficult to claim exclusive rights over news and political commentary. During the seventeenth century, censorship and literary property were linked, and news of state officially belonged to the monarch. Stationers who obtained authorization to publish accounts of battles, crimes, or natural disasters could and did claim exclusive rights over ballads, pamphlets, and periodicals, though of course registration did not eliminate the problem of piracy. During the eighteenth century, by contrast, news became the property of the public, and in a journalistic culture that privileged the free circulation of anonymous paragraphs and pseudonymous essays, it because increasingly difficult to argue that accounts of current events could be owned.

In hindsight, the lack of copyright for newspaper and magazine writings in eighteenth-century Britain could be seen as a legacy of the Act of Anne, which ended up restricting not only the duration and scope of literary property but also the range of works seen to qualify for it. But as Deazley has emphasized, the act was highly ambiguous. For periodical writings as for translations and abridgements, this ambiguity created a space for writers, printers, and booksellers to work out shared norms and practices. Initially they experimented with the new law by registering their periodicals. But after I 720 , very few news publications were entered. After a brief but important debate on the subject in the I730s, there was very little discussion of copyright for periodical writings. The collective decision to turn away from copyright cannot be understood by appealing to the language of legislation 
or judicial opinions; it was the result of a specific journalistic culture created by writers, printers, and booksellers in eighteenth-century London.

The lack of copyright for periodical writings should not be seen as a failure of eighteenth-century writers and publishers to "catch up" by acquiring the kind of protection already available for books. Rather, the underlying economics and dominant cultural practices of eighteenth-century journalism worked against the very idea of literary property for periodical writings. Reprinting would not have thrived for so long if writers, printers, booksellers, and readers had not derived benefits from it. While some planted stories or mislabeled sources in an attempt to advance political or financial goals, others cherished the ability to assume a depersonalized voice in debates about culture, society, and government. ${ }^{88}$ Reprinting went hand in hand with disguised authorship in defining the eighteenth-century republic of letters. As Richard Russel recognized, copying not only enabled news (true and false) to spread, it also facilitated commentary and analysis.

\section{Notes}

The author would like to thank the following scholars for comments on various drafts and/or useful bibliographical references: Lionel Bently, Ronan Deazley, Ian Gadd, Michael Harris, Robert Mankin, James McLaverty, Robin Myers, Shef Rogers, Simon Stern, and Martha Woodmansee.

I. For the text of the act, see Lionel Bently and Martin Kretschmer, eds., Primary Sources on Copyright (I450-I900), www.copyrighthistory.org (accessed June 26, 20I2). For a survey of copyright history, see John Feather, Publishing, Piracy and Politics: An Historical Study of Copyright in Britain (London: Mansell, 1994).

2. In Australia, by contrast, such legislation was achieved. See Lionel Bently, "Copyright and the Victorian Internet: Telegraphic Property Laws in Colonial Australia," Loyola of Los Angeles Law Review 38 (2004): 7I-I76; and Lionel Bently "The Electric Telegraph and the Struggle over Copyright in News in Australia, Great Britain and India," in Copyright and the Challenge of the New, ed. Brad Sherman and Leanne Wiseman (Alphen aan den Rijn: Kluwer Law International, 20I2), 43-76.

3. See Robert Brauneis, "The Transformation of Originality in the Progressive-Era Debate over Copyright in News," Cardozo Arts \& Entertainment Law Journal 27 (2009): 32 I-373.

4. For the eighteenth-century debates, see Mark Rose, Authors and Owners: The Invention of Copyright (Cambridge, Mass.: Harvard University Press, I993); and Ronan Deazley, On the Origin of the Right to Copy: Charting the Movement of Copyright Law in EighteenthCentury Britain (I695-I775) (Oxford: Hart Publishing, 2004). On contemporary attitudes toward imitations, abridgments, and excerpts, see Simon Stern, "Copyright, Originality, and the Public Domain in Eighteenth-Century England," in Originality and Intellectual Property in the French and English Enlightenment, ed. Reginald McGinnis (New York: Routledge, 2008), 69-IOI. Accounts of eighteenth-century journalism that do consider the question of copyright tend to assume that it simply did not apply to periodical writings-for example, James Sutherland, The Restoration Newspaper and Its Development (New York: Cambridge University Press, I986), 42; and Iona Italia, The Rise of Literary Journalism in the Eighteenth Century: Anxious Employment (London: Routledge, 2005), I I 4. 
5. Adrian Johns, Piracy: The Intellectual Property Wars from Gutenberg to Gates (Chicago: University of Chicago Press, 2009).

6. Ronan Deazley, "Commentary on the Statute of Anne (I7IO)," in Bently and Kretschmer, Primary Sources on Copyright.

7. Michael Treadwell, "The Stationers and the Printing Acts at the End of the Seventeenth Century," in The Cambridge History of the Book in Britain, Vol. 4, I557-I695, ed. John Barnard and D. F. McKenzie (Cambridge: Cambridge University Press, 2002), 75 5-778; Shef Rogers, "The Use of Royal Licenses for Printing in England, I695-I760: A Bibliography," The Library, 7 th ser. I, no. 2 (June 2000): I33-I92.

8. Hyder Rollins, An Analytical Index to the Ballad-Entries (I 557-I709) in the Registers of the Company of Stationers of London (Chapel Hill: University of North Carolina Press, I924), I.

9. Carolyn Nelson and Matthew Seccombe, "The Creation of the Periodical Press, I620-I695," in Barnard and McKenzie, Cambridge History of the Book in Britain, 4:533-550 (quotation at 535). On the proportion of extant printed works that were registered, see D. F. McKenzie, "Printing and Publishing I 5 57-I700: Constraints on the London Book Trades," in ibid., $553-567$.

IO. The first corantos produced in London in I62I were not registered, probably because their printers sought to avoid trouble with the authorities. Corantos began to be registered in May I622. Nelson and Seccombe, "Periodical Press," 536-539. During the Civil War, newsbooks only began to be registered after the ordinance of I 643 , and not all publishers followed the law scrupulously. Joad Raymond, The Invention of the Newspaper: English Newsbooks I64I-I 649 (Oxford: Clarendon Press, I996), 28-29, 60-6I, 77-78. For the entries, see Edward Arber, ed., A Transcript of the Registers of the Company of Stationers of London; I 554I640 A.D., 5 vols. (London: privately printed, I875-I894); and [G. E. B. Eyre], A Transcript of the Registers of the Worshipful Company of Stationers; From I640-I708 A.D., 3 vols. (London: privately printed, I9I3).

II. "An Ordinance for the Regulation of Printing, London (I643)," in Bently and Kretschmer, Primary Sources on Copyright.

I2. In I648 there was a dispute between John Dillingham (an author) and Robert White (a printer) over the sole right to publish a periodical called The Moderate Intelligencer. White had entered the title with the Stationers' Company, but the House of Lords awarded the title to Dillingham for what appears to have been political reasons. White eventually changed his title to The Moderate and published on a different day. William Clyde, The Struggle for Freedom of the Press from Caxton to Cromwell (Oxford: Oxford University Press, I934), I45-I47. On claims of usurpation more generally, see Jason Peacey, “The Counterfeit Silly Curr': Money, Politics, and the Forging of Royalist Newspapers during the English Civil War," Huntington Library Quarterly 67, no. I (2004): 27-58.

I3. "Licensing Act, London (I 662)," in Bently and Kretschmer, Primary Sources on Copyright.

I4. Deazley, On the Origin of the Right to Copy, ch. I.

I 5. Qtd. in ibid., I 5. In late I696 the Commons briefly considered a "Bill to prevent the Writing, Printing, and Publishing any News without License." Qtd. in ibid., I 8.

I6. In 1703 How published an unauthorized edition of Daniel Defoe's writings, an incident that remained in Defoe's mind as he wrote his own Essay on the Regulation of the Press in I704. Jody Greene, The Trouble with Ownership: Literary Property and Authorial Liability in England, I660-I730 (Philadelphia: University of Pennsylvania Press, 2005), I07.

I7. John How, Some Thoughts on the Present State of Printing and Bookselling (London: author, I709), II.

I8. A separate Act of Parliament extended protection to printed engravings in I734. See David Hunter, "Copyright Protection for Engravings and Maps in Eighteenth-Century Brit- 
ain," The Library 6, no. 9 (I987): I28-I47. Music composers relied upon royal licenses as well as registration under the Act of Anne. Music registrations rose significantly after the case of Bach v. Longman (I777), in which the King's Bench confirmed that musical scores were eligible for protection under the Act of Anne. See John Small, "J. C. Bach Goes to Law," Musical Times I26 (I985): 526-529; Rogers, "Use of Royal Licenses," I39, I47, I 58, I66; and Michael Kassler, ed., Music Entries at Stationers' Hall I7IO-I 8 I 8 (Aldershot: Ashgate, 2004).

I9. Qtd. in Ronan Deazley, "The Statute of Anne and the Great Abridgment Swindle," Houston Law Review 47, no. 4 (2010): 793-8I 8 (quotation at 796). See also Ronan Deazley, "Commentary on Gyles v. Wilcox (I74I)," in Bently and Kretschmer, Primary Sources on Copyright.

20. Stern, "Copyright, Originality, and the Public Domain."

2I. Deazley, "Statute of Anne and the Great Abridgment Swindle," especially 798-80I; William St. Clair, The Reading Nation in the Romantic Period (Cambridge: Cambridge University Press, 2004), ch. 4 .

22. St. Clair claimed that "monopolist" booksellers in the eighteenth century "outlawed" the reprinting of books or parts of books in periodicals. St. Clair, Reading Nation in the Romantic Period, 99-Io0. He admitted that journals such as the Monthly Review and the Critical Review quoted extensively from books, but he did not examine the role of periodicals in disseminating texts during the eighteenth century. On books published in "numbers," see R. M. Wiles, Serial Publication in England before 1750 (Cambridge: Cambridge University Press, I957). On the role of reviews, see Patricia Gael, "The Origins of the Book Review in England, I663-I 749," The Library, 7th ser. I3, no. I (March 2012): 63-89.

23. Robin Myers, ed., Records of the Worshipful Company of Stationers 1554-1920 (Cambridge: Chadwyck-Healey, I987), part I, reel 6: I2, 76, 88-9I, I I3, I I 8, I 29, I34, I36, I49, I65, I73, 206, 2I 2, 2 I9.

24. Michael Harris, London Newspapers in the Age of Walpole: A Study of the Origins of the Modern English Press (Cranbury, N.J.: Associated University Presses, 1987), 19-22.

25. Ibid., I 42.

26. If the fee (6d per title) and deposit requirements (nine copies of each work) had been applied to every issue of a periodical, then the cost would have dissuaded many publishers from registering their periodicals. But these registration rules were not strictly applied at first. Instead of paying for each issue, many publishers in the I7IOs entered the title once, mentioning that it was "to be continued weekly." They did not all furnish the required nine copies. Myers, Records, part I, reel 6.

27. Richmond P. Bond, "The Pirate and the Tatler," The Library 5 th ser. I8, no. 4 (December I963): 257-274; Calhoun Winton, "The Tatler: From Half-Sheet to Book," Prose Studies I6, no. I (April I993): 23-33.

28. Qtd. in Sutherland, Restoration Newspaper, 34.

29. Myers, Records, part I, reel 6: 2I 4, 227, 229.

30. Qtd. in Harris, London Newspapers, 2 I.

3I. Evening Post, January 26-28, I710.

32. Evening Post, January I9-2 I, I 7 IO. Many issues of this newspaper contain postscripts on page 3 and no printing on page 4 . Space was intentionally left blank so that purchasers could add handwritten messages before forwarding papers to their correspondents in the countryside.

33. G. A. Cranfield, The Development of the Provincial Newspaper I700-I760 (Oxford: Clarendon Press, I962), IO-I2, 28-29.

34. Michael Harris, "The Management of the London Newspaper Press during the Eighteenth Century," Publishing History 4 (I978): 95-I I2; C. Y. Ferdinand, Benjamin Collins and the Provincial Newspaper Trade in the Eighteenth Century (Oxford: Clarendon Press, 1997), 5I-63; Michael Harris, "London Newspapers," in The Cambridge History of the Book in 
Britain, Vol. 5, I695-I830, ed. Michael Suarez and Michael Turner (Cambridge: Cambridge University Press, 2009).

35. The proportion of "original" material increased substantially over time. Although original essays and poems made up little more than Io percent of each issue in 1735 , by Cave's death in 1754 they accounted for more than 90 percent of the magazine's content. Estimates of Titia Ram cited by James Tierney, "Periodicals and the Trade, I695-I780," in Suarez and Turner, Cambridge History of the Book in Britain, 479-497 (figures at 488-489).

36. Advertisement in Grub-Street Journal (hereafter cited as GSJ), April 27, I732, 4.

37. D. F. McKenzie and J. C. Ross, eds., A Ledger of Charles Ackers: Printer of "The London Magazine" (Oxford: Oxford Bibliographical Society, I968), 4-5.

38. GSJ, March I $5, \mathrm{I}_{732} / 33$.

39. For more on Russel and the GSJ, see Bertrand Goldgar, ed., The Grub Street Journal, I730-33 (London: Pickering \& Chatto, 2002), vol. I, editor's introduction; and Bertrand Goldgar, "The Grub Street Journal: Construction and Control of its Readership," in Sustaining Literature: Essays on Literature, History, and Culture, I500-I800, ed. Greg Clingham (Cranbury N.J.: Associated University Presses, 2007), 97-I08.

40. Advertisement for Gentleman's Magazine printed in GSJ, May 4, I732, 4.

4I. Letter "To Mr. Edward Cave," signed Thomas Cox, John Wilford, John Clarke, Thomas Astley, and Charles Ackers, printed in GSJ, May I 8, I732, 4.

42. Italia, Literary Journalism, I I4. ers, 6 .

43. Weekly Register, June 3, I732, quoted in McKenzie and Ross, Ledger of Charles Ack-

44. GSJ, May 25, I732.

45. Italia, Literary Journalism, I I 4-I I 6.

46. GSJ, May 25, I732.

47. Between I 692 and I694 Peter Anthony Motteux issued the Gentleman's Journal; or, The Monthly Miscellany, and his periodical had a number of imitators. See Tierney, "Periodicals and the Trade, I695-I780," 487-492.

48. GSJ, May I8, I732.

49. GSJ, March I $5, \mathrm{I}_{732} / 33$.

50. GSJ, March 22, I732/33.

5I. GSJ, April 5, I733.

52. See Lucas Graves, "The Affordances of Blogging: A Case Study in Culture and Technological Effects," Journal of Communication Inquiry 3 I, no. 4 (October 2007): 33 I-346.

53. Qtd. in Harris, London Newspapers, I60.

54. Daily Courant, March I2, I702.

55. GSJ, March 24, I736/37.

56. Cranfield, Provincial Newspaper, 30-3 I.

57. GSJ, January $3, \mathrm{I} 733 / 34$.

58. GSJ, April 8, I736.

59. Ibid.

60. Qtd. in Harris, London Newspapers, I62.

6I. GSJ, September I2, I734.

62. Ibid.

63. GSJ, March 3, $1736 / 37$.

64. GSJ, March I0, I736/37.

65. Russel may have been involved in another venture called the Literary Courier of Grub Street, which apparently only lasted for a few months in early I738. Piracy was again a problem, and in an effort to dissuade others from reprinting their articles, the proprietors announced their intention to prosecute infringers: "The proprietors of the above Paper have, pursuant to an Act of Parliament passed in the 8th Year of the late Queen Ann, made for the Encourage- 
ment of Learning, Entred it in the Regise-Book [sic] of the Stationers Company, pursuant to the Direction of the said Act; and do intend, as they publish the same from time to time, so to do, in Order to preserve their Right therein: And therefore the said Proprietors do hereby give this publick Notice, that they are determined, in case any of the Original Letters, Essays, Poems, or other Writings, that shall hereafter be inserted in the said Paper, be pirated or printed in any Monthly Magazine or Collections, that the said Proprietors have empowered Mr. Jos. Grove, their Attorney, to proceed against such Person, or Persons, as shall infringe upon their Property contrary to Law." London Daily Post, and General Advertiser, June I, I738, I.

66. Memoirs of the Society of Grub-Street, 2 vols. (London: printed for J. Wilford, I737), I:xiii.

67. Ibid.

68. Qtd. in Robert Hume, "The Economics of Culture in London, I660-I740," Huntington Library Quarterly 69, no. 4 (December 2006): 487-533 (quotation at 5I4).

69. Michael Harris, "Journalism as a Profession or Trade in the Eighteenth Century," in Author/Publisher Relations during the Eighteenth and Nineteenth Centuries, ed. Robin Myers and Michael Harris (Oxford: Oxford Polytechnic Press, I983), 37-62; Jeremy Black, The English Press in the Eighteenth Century (London: Croom Helm, I987), 87-I04; J. A. Downie, "Periodicals, the Book Trade and the 'Bourgeois Public Sphere," Media History I4, no. 3 (2008): 26I-274.

70. Memoirs of the Society of Grub-Street, vol. I: xvii.

7I. Ibid., vol. I:xiv-xix.

72. Ibid., vol. I:xviii-xix.

73. Ibid., vol. I: xxii.

74. "Booksellers Bill, London (I737)," in Bently and Kretschmer, Primary Sources on Copyright.

75. Tonson v. Collins ( 1769 ) concerned the Spectator, which began its life as a periodical, but neither side addressed that fact because by the I760s the value of the copyright clearly resided in the exclusive right to reprint the collected essays in book form.

76. Qtd. in Deazley, "Commentary on Gyles v. Wilcox (I74I)."

77. Ibid.

78. In order to determine whether an abridgement was "fair" or "elusory," the judge (Sir Thomas Clarke) argued that "the court must take notice of the springs flowing from the trade; and though they cannot regard customs of trade as binding, yet [the court] will consider the consequences of them." Qtd. in ibid. The plaintiff, Robert Dodsley, had tried to impose a very different trade custom than Cave's. He argued that periodicals should avoid reprinting too much from other periodicals or from pamphlets so as not to offend their rightful owners. See Robert Dodsley to William Strahan, I 4 January I757, in The Correspondence of Robert Dodsley, I733-I764, ed. James Tierney (Cambridge: Cambridge University Press, I988), vol. I: 258-260. Dodsley sued Kinnersley in hopes of legitimating the trade custom that he was trying to establish, but he lost in part because excerpts of the book in question had already appeared in Dodsley's own periodical.

79. Harris, London Newspapers, I2I, I84-I 85.

80. In January I 742 David Hume remarked that Walpole "is the Subject of above Half the Paper that has been blotted in this Nation within these Twenty Years." David Hume, Essays, Moral and Political (Edinburgh: A. Kincaid, I742), 2:203.

8I. For more on these developments, see Bob Clarke, From Grub Street to Fleet Street: An Illustrated History of English Newspapers to I 899 (Aldershot: Ashgate, 2004); and Hannah Barker, Newspapers, Politics, and Public Opinion in Late Eighteenth-Century England (New York: Oxford University Press, I998).

82. Will Slauter, "Le paragraphe mobile: circulation et transformation des informations dans le monde atlantique du I8e siècle," Annales: Histoire, sciences sociales 2012, no. 2 
(April-June 20I2): 363-389, also available in English translation as "The Paragraph as Information Technology: How News Traveled in the Eighteenth-Century Atlantic World," Annales: H.S.S. $20 \mathrm{I} 2$, no. 2: $253-278$.

83. On openness to copying as one of the defining features of the press during this period, see William Warner, "Communicating Liberty: The Newspapers of the British Empire as a Matrix for the American Revolution," English Literary History 72, no. 2 (Summer 2005): 339-36r.

84. Qtd. in John Brewer, Party Ideology and Popular Politics at the Accession of George III (Cambridge: Cambridge University Press, I976), 224.

85. Qtd. in Barker, Newspapers, 44.

86. Qtd. in Cranfield, Provincial Newspaper, 97-98.

87. Ibid., I63-I66.

88. See Michael Warner, Letters of the Republic: Publication and the Public Sphere in Eighteenth-Century America (Cambridge, Mass.: Harvard University Press, I990); and David Shields, Civil Tongues and Polite Letters in British America (Chapel Hill: University of North Carolina Press, I997). On accusations of manipulation, see Will Slauter, "Forward-Looking Statements: News and Speculation in the Age of the American Revolution," Journal of Modern History 8I (December 2009): 759-792. 